\title{
ROMANIA IN EU CONTEXT. COMPETITIVENESS AND KNOWLEDGE-BASED ECONOMY
}

\author{
Professor PhD Gheorghe Zaman \\ Corresponding member of Romanian Academy \\ PhD Blănaru Adrian
}

\begin{abstract}
The paper analyses Romania's competitiveness and knowledge-based economy in an EU comparative context for the 2006-2007 period.

The main compared pillar-indices are the following: global competitiveness index; higher education and training; technological readiness; business sophistication; innovation. Each pillar index is disaggregated into several relevant sub indices. Comparisons are made between Romania and EU-25, EU-10 (new member states since 2004), Bulgaria and Turkey on the basis of positions and scores of each country or group of countries, within a total framework of 131 countries. The size of Romania's "digital divide" vis-à-vis EU-25 can be used as a tool for national priority setting and better policies regarding catching up and convergence processes in digital economy.
\end{abstract}

Keywords: competitiveness; knowledge-based society; national and international value chains; catching-up; convergence; digital divide; brain drain; knowledge creation, absorption and diffusion.

JEL Codes: E00.

\section{Romania's advantages/disadvantages at international level}

The analysis of Romania's competitive advantages/disadvantages in an international comparative context provides an useful tool for decision-makers in their current and long term activities.

At microeconomic level, competitive advantages mean the superior profitability situation of a company against others. In accordance with to the concept of M.Porter ${ }^{*}$, sustainable competitive advantages are achieved by a company when it realises the same profit at lower costs than the competitors (cost advantage) or obtains higher profits as compared with its competitors for competitive products (differentiation advantage). The competitive advantage allows the company to provide for higher value for the consumer and, at the same time, to realise a superior profit. Based on the two types of advantages (costs and differentiation), the company achieves a leading position the characteristic of which is represented by the creation of superior values as result of using own resources (patents, trademarks, know-how, goodwill, brands, reputation, etc.) and efficient use capacities thereof within a system of value chains, positioned horizontally and vertically.

The theory of competitive advantages, in a more encompassing and dynamic approach does not represent anything else but the theory of comparative advantages (costs), studied in their evolution in time. Therefore, one of the major issues of competitive advantages is their sustainability on various periods of time as top performances, as already known, are difficult to maintain especially on long term.

Competitive advantages require special schemes of strategic management which take into account maintaining a unique competitive position, the compromise and selection of competitors, coherence, synergy and efficiency of activities. The background of competitive advantages from a

\footnotetext{
* Porter M.E., Competitive advantage: Creating and Sustaining Superior Performance.
} 
strategic understanding is the effort to imprint the perpetuity of the innovation process that should be stimulated, maintained and developed based on various strategies of the innovation system of entrepreneurial creativity.

The shift from the microeconomic approach of competitive advantages to the macroeconomic one was a natural process because the basic set of competitiveness principles remains, unchanged. What changes is the metric of competitive advantages (the system of indicators and sub-indicators) as well as policies, instruments and stimulation mechanisms of the latter.

At micro- and macroeconomic level as well, an own system of competitiveness indicators was created with various levels of aggregation depending on the objectives and research field, and on the available information.

The objective pursued with respect to the analysis of the competitive advantages of Romania consisted in revealing the position of Romania in the international hierarchy of competitiveness, understood in a complex multi-criteria and multi-factorial approach, of the competitiveness gaps in which is attempted to intertwine the macro- with the micro level.

The competitive advantages (CA) of a country or of a region represent the performances of a multitude of activities of private and state companies from a country or region, which aim to the top level of international performances. The CA concept reveals the microeconomic aspects of $\mathrm{CA}$ and the macroeconomic ones as well, starting from the premise that the largest part of competition and international trade develops between companies and not between countries and that, still, there are some particularities, attributions and characteristics that affect the success probability of a company at international level and that these have particular relevance for various industries and sectors.

The international competitiveness of a country represents the degree to which the respective country may generate goods and services under the conditions of a free and fair market which can satisfy the demand on international markets maintaining or increasing the real incomes of citizens.

In determining the size of CA it is necessary to take into account the fact that, in the case of a country with high trade deficit which is persistent and in increase as share of the GDP, heightening the volume of exports does not mean also a raise of its incomes if for this growth one remedy was the depreciation of the national coin.

In the specialised literature* the following stages of competitive development are determined in accordance with the CA sources:

- The predominant stage of the basic production factors' impact (including labour) which represent the main source of advantages; in this stage the substitution policy of imports does not represent a way of sustaining development, because the quality of the higher production factors cannot be improved by their protection against external competition;

- The predominant stage of investments' impact where the complex and more advanced production factors is added to the basic ones, in parallel with the strong development of domestic competition and the beginnings of shaping an internal market where an increase of demand takes place, particularly for certain segments with low value added in various sectors and industries.

In this stage the "scale effect" is important, retaining the labour component to a higher share, and the international competition is generated for the relationship price/cost. The investments are realised, actually, by all economic agents (companies, workers, families and government), including here also by sectorial allotment of the capital. The dilemmas of this stage are whether the protection of "new industries", the promotion of exports, including the opening of domestic markets, improves or not the competitive advantage.

- The predominant role of innovation in which the "engine" of intangible capital begin to function. It is interesting to mention that the motivation of innovation is made specifically in the

\footnotetext{
* University of Washington, Geography 349, professor Harrington P., Who's Competing with Whom?...And with what Consequences for Whom?, http://faculty.washington.edu/jwh/3491ec07.htm
} 
sectors in which are recorded rather disadvantages than competitive advantages. A vertical sharpening of the advantage takes place because the capabilities and demands between suppliers and consumers from key-industries increase, as the "technology multiplying" phenomenon takes place. The government stimulates demand for the creation of advanced technological factors, maintaining the competition undistorted and applying the principle of the new theory of the trade based on technologies which takes into consideration the following key-factors:

a) technological progress creates external scale economies (positive externalities) from which benefits the entire economy, beyond the innovative company by the dissemination process of knowledge and redistribution of the labour force;

b) increasing the role of internal economies of scale, in the case of innovative companies, which use top technologies.

The mentioned factors act at national and regional level providing favourable premises for consolidating CA.

- The dominant stage of the wealth factor, when a nation and its economic sectors spend investments for growth, productivity and innovation. In this stage sub-investments in industry occur. The issue is whether such a stage can keep longer in time.

The development of the competitive advantages theories is, currently, marked by the fact that the new theories of foreign trade justify a more or less significant role of the government in creating comparative advantages. The traditional theories of the comparative and absolute advantages (Smith and Ricardo) and their versions according to Hecksher, Ohlin and Samuelson did not take into account such a role of the government.

Theorists, such as P. Krugman consider that governments may have a certain role in realising international trade advantages when they support national companies to have leader positions in a certain field or to exceed certain obstacles on entering on the market. In his turn, Porter M.E. * underlines the fact that the government, at all levels, may improve or, to the contrary, worsen the national competitive advantage by the influence exercised through the antitrust policy, by the legal framework, investments in education and public acquisitions.

The theoretic substantiation of the competitive advantages analysis is represented by the socalled "diamond" model of Porter according to which competitiveness has four determinant factors: endowment with factors; structure and strategy of the company; demand conditions; supported and interconnected industries. Starting from the premise that governments cannot control the national competitive advantage but only influence it, Porter highlights some criteria and principles of the policies mix, which should be taken into account by governments when they undertake to support the national competitive advantage, that is:

- in industry, companies and not nations are in competition;

- the competitive advantage of a nation in industry is relative ${ }^{1}$;

- dynamism leads to competitive advantage and not cost advantages on short-term;

- national economic prosperity requires that industries are modernised;

- a competitive advantage of the nation in industry, often, is focused from the geographic viewpoint;

- a competitive advantage of a national industry is created within a decade or even more and not in three to four years business cycles;

- the nations gain advantages due to differences and not similitude;

- several classifications used for differentiating or prioritising industries have small relevance;

- the process of supporting advantage may be particularly uncomfortable for companies and for those working in the respective companies.

The analysis of creating and developing competitive advantages of Romania must be based

\footnotetext{
* Porter M.E, (1990) The Competitive Advantage of Nations, Free Press, New York

${ }^{1}$ Hence the opinion that competitive advantages represent dynamised comparative (relative) advantages.
} 
precisely on their modern concept substantiated in the works of Porter M.E. and subsequently developed in other works or international economic institutions.

Several contemporary authors consider that the innovation process at the basis of competitive advantages must take into consideration the major meaning of the aphorism "nothing exists without order and nothing progresses without chaos!" In this sense, appeared also the necessity of creation and innovation freedom, called "jazz of innovation".

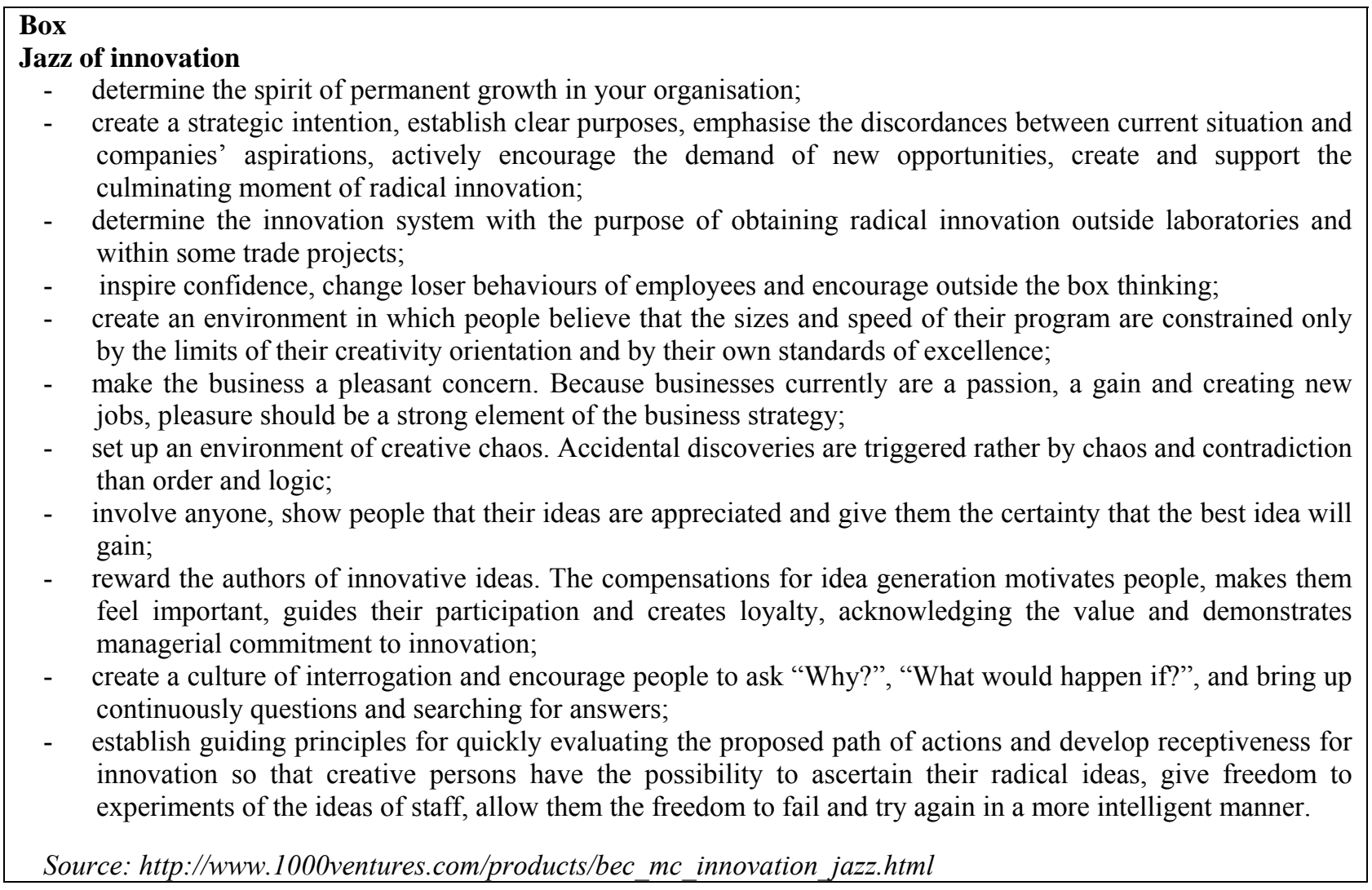

The capacity of understanding, adopt and apply the generating principles of CA suggested in the specialised literature represent just the key of national $\mathrm{CA}$, the cornerstone of strategic management at micro and macroeconomic level.

\section{The competitive advantages indicators' system}

The competitiveness of a national economy, in the widest understanding from the viewpoint of the factors of influence is researched by special methods of corroborating several systems of indicators which are directly and/or indirectly related with the competitive advantages in broad sense*. The studies developed within the World Economic Forum are based on the calculation of a global competitiveness index which comprises 9 main pillars-categories of indicators, that is:

- institutions (property rights, ethics and corruption, traffic of influence, governmental inefficiency, bureaucracy, bribe, security, behaviour of private companies, responsibility);

- infrastructure ( quality of transport ways, phone lines, etc.);

- macroeconomic indicators (budgetary deficit/surplus, gross capital formation rate, inflation, interest, exchange rate, trade deficit/surplus);

- health and primary education indicators;

- higher education and vocational training indicators (quality of the educational system,

\footnotetext{
${ }^{*}$ See: The Global Competitiveness Report 2006-2007, in World Economic Forum.
} 
share of exact sciences, schools management, etc.);

- indicators of market efficiency: markets for goods and services (distortions, competition, and size);labour market (flexibility, efficiency); financial markets (sophistication and openness degree);

- indicators of technological readiness- (technological level, absorption capacity of technologies, technological transfer and FDI, mobile phones, ITC, Internet-users, PCs);

- complexity degree (sophistication) of businesses (networks and support industries, complexity of companies and strategies, nature of competitive advantages, value of value chains presence);

- innovation indicators (research quality, patents, licenses, protection of intellectual property, innovation capacity).

All these indicators, in corroborated and/or disaggregated form finally contributed to the hierarchy (position) of the 131 countries after their size in decreasing order, taking into account also the size of obtained scores.

In order to see which is the level of global competitiveness of Romania, in the international context, we have chosen some comparative milestones among which EU-25, EU-10*, Bulgaria and Turkey for the years 2006-2007, considering that these have a covering representativeness degree for the purposes of our analysis which aims to determine the size of the competitiveness lags against developed countries of the EU and against the new member countries of the EU from Central and Eastern Europe which adhered in the year 2004. Bulgaria was chosen as term of comparison considering that it adhered to EU in the same year as Romania and that it is a neighbouring country and Turkey was selected on considerations of neighbourhood and of important trading partner for Romania which, according to some viewpoints, presents some quasi-similitude to our country as development level and of economic evolution.

\footnotetext{
* New countries, members of the EU as of 2004.
} 
Table no. 1

Global competitiveness indicators for Romania against

$E U-25, E U-10$, Bulgaria and Turkey, in the years 2006-2007

\begin{tabular}{|c|c|c|c|c|c|c|c|c|c|c|}
\hline \multirow{2}{*}{$\begin{array}{c}\text { Category (pillars) } \\
\text { of the } \\
\text { competitiveness } \\
\text { indicators } \\
\end{array}$} & \multicolumn{2}{|c|}{ Romania } & \multicolumn{2}{|c|}{ EU-25* } & \multicolumn{2}{|c|}{ EU-10* } & \multicolumn{2}{|c|}{ Bulgaria } & \multicolumn{2}{|c|}{ Turkey } \\
\hline & Position & Score & Position & Score & Position & Score & Position & Score & Position & Score \\
\hline $\begin{array}{l}\text { Index of global } \\
\text { competitiveness }\end{array}$ & 68 & 4.02 & - & 4.97 & - & 4.50 & 72 & 3.96 & 59 & 4.14 \\
\hline -Efficiency factors & 55 & 3.99 & - & 4.87 & - & 4.55 & 70 & 3.67 & 54 & 4.02 \\
\hline - Innovation factors & 73 & 3.52 & - & 4.62 & - & 4.00 & 85 & 3.26 & 42 & 3.96 \\
\hline $\begin{array}{l}\text { 1.Pillar } \\
\text { "Institutions" }\end{array}$ & 87 & 3.40 & - & 4.76 & - & 4.17 & 109 & 3.07 & 51 & 4.05 \\
\hline $\begin{array}{l}\text { 2. Pillar } \\
\text { „Infrastructure” }\end{array}$ & 77 & 3.05 & - & 5.03 & - & 4.28 & 65 & 3.41 & 63 & 3.46 \\
\hline $\begin{array}{l}\text { 3. Pillar } \\
\text { "Macroeconomic" }\end{array}$ & 97 & 3.94 & - & 4.76 & - & 4.62 & 35 & 4.92 & 111 & 3.58 \\
\hline $\begin{array}{l}\text { 4. Pillar } \\
\text { "Health and } \\
\text { primary } \\
\text { education" }\end{array}$ & 69 & 6.38 & - & 6.71 & - & 6.54 & 6.61 & 6.9 & 78 & 6.28 \\
\hline $\begin{array}{l}\text { 5. Pillar "Higher } \\
\text { education and } \\
\text { vocational } \\
\text { training" } \\
\end{array}$ & 50 & 4.34 & - & 5.15 & - & 4.89 & 62 & 4.05 & 57 & 4.15 \\
\hline $\begin{array}{l}\text { 6. Pillar "Market } \\
\text { efficiency" }\end{array}$ & 76 & 4.03 & - & 4.73 & - & 4.44 & 90 & 3.75 & 47 & 4.35 \\
\hline $\begin{array}{l}\text { 7. Pillar } \\
\text { "technological } \\
\text { readiness" }\end{array}$ & 49 & 3.59 & - & 4.74 & - & 4.38 & 68 & 3.21 & 52 & 3.56 \\
\hline $\begin{array}{l}\text { 8. Pillar "Business } \\
\text { complexity } \\
\text { (sophistication } \\
\text { degree)" }\end{array}$ & 73 & 3.89 & - & 5.07 & - & 4.46 & 84 & 3.59 & 39 & 4.58 \\
\hline $\begin{array}{l}\text { 9. Pillar } \\
\text { "Innovation" }\end{array}$ & 68 & 3.14 & - & 4.17 & - & 3.54 & 87 & 2.93 & 51 & 3.35 \\
\hline
\end{tabular}

* for EU-25 and EU-10 (member countries as of 2004) was used the un-weighted arithmetic average of the countries from the respective areas .

Source: Own calculations and data from The Global Competitiveness Report 2006-2007. World Economic Forum. 2007.

The data from Table 1 highlight the following conclusions regarding Romania's competitiveness against the one of other countries, with comparison term in the year 2006-2007:

- against the levels of the EU-25 and EU-10 levels Romania was placed under their size for all indicators (pillars) of competitiveness, recording score differences (lags), as follows:

\begin{tabular}{|c|c|c|c|c|c|c|c|c|c|c|c|c|}
\hline & \multicolumn{3}{|c|}{$\begin{array}{c}\text { Global competitiveness index } \\
\text { (GCI) }\end{array}$} & \multicolumn{9}{|c|}{ Pillars } \\
\hline & Total & Efficiency & Innovation & 1 & 2 & 3 & 4 & 5 & 6 & 7 & 8 & 9 \\
\hline EU-25 & -0.95 & -0.88 & -1.10 & -0.36 & -1.98 & -0.82 & -0.33 & -0.81 & -0.70 & -1.15 & -1.18 & -0.93 \\
\hline EU-10 & -0.57 & -056 & -0.48 & -0.77 & -1.23 & -0.68 & -0.16 & -0.50 & -0.41 & -0.79 & -0.57 & -0.40 \\
\hline Bulgaria & +0.06 & +0.32 & +0.26 & $\begin{array}{c}+0.3 \\
7\end{array}$ & -0.35 & -0.98 & -0.23 & +0.29 & +0.28 & +0.38 & +0.30 & +0.21 \\
\hline Turkey & -0.12 & -0.03 & -0.44 & -0.65 & -0.41 & +0.36 & +0.10 & +0.19 & +0.32 & +0.03 & -0.69 & -0.21 \\
\hline
\end{tabular}

The signs (+) and (-) mean advantage, respectively competitive disadvantage for Romania.

Source: Own calculations and data from The Global Competitiveness Report 2006-2007. World Economic Forum. 2007. 
- Bulgaria exceeded Romania as competitiveness level for the pillars: infrastructure; macroeconomic; health and primary education;

- Turkey recorded inferior scores of competitiveness against Romania for the pillars macroeconomic; health and primary education; higher education and vocational training; technological readiness;

- in the hierarchy of the 131 countries considered in the study, as a rule, Romania took a middle position, the weakest positions being recorded for the pillars macroeconomic, institutions, infrastructure, market efficiency, business complexity that represent areas for which in the future it is necessary to undertake with priority measures for improving the performances.

Hereunder, we shall present the situation of Romania's competitiveness in the years 20062007, based on analysing the position and the size of scores, in the comparative context of the 131 countries for a series of indicators which aim directly its foreign trade and efficiency of the latter against the same countries and groups of countries as in the previous analysis. It is about the pillars: infrastructure; macroeconomic; higher education and vocational training; market efficiency; technological readiness; business complexity; innovation.

Each of the mentioned pillars will be separately studied, disaggregated on several indicators or factors of influence.

\section{Infrastructure}

The quality of infrastructure of a country represents one of the important factors for developing international economic relations. Depending on its qualitative level, this factor may turn into a competitive advantage/disadvantage, in international context and represents one of the driving forces, the development of which must precede the start up of other sectors of economy.

Table no. 2

Competitiveness indicators of Romania in the field of infrastructure as compared with $E U-25$, EU-10, Bulgaria and Turkey, in the years 2006-2007

\begin{tabular}{|c|c|c|c|c|c|c|c|c|c|c|}
\hline \multirow{2}{*}{$\begin{array}{l}\text { Category (pillars) of } \\
\text { the competitiveness } \\
\text { indicators }\end{array}$} & \multicolumn{2}{|c|}{ Romania } & \multicolumn{2}{|c|}{ EU-25* } & \multicolumn{2}{|c|}{ EU-10* } & \multicolumn{2}{|c|}{ Bulgaria } & \multicolumn{2}{|c|}{ Turkey } \\
\hline & Position & Score & Position & Score & Position & Score & Position & Score & Position & Score \\
\hline Infrastructure, total & 77 & 3,05 & - & 5.03 & - & 4.28 & 65 & 3.41 & 63 & 3.46 \\
\hline $\begin{array}{l}\text { 1.General quality of } \\
\text { infrastructure }\end{array}$ & 101 & 2.36 & - & 5.11 & - & 4.34 & 89 & 2.65 & 64 & 3.51 \\
\hline $\begin{array}{l}\text { 2.Railroad } \\
\text { infrastructure } \\
\text { development }\end{array}$ & 54 & 2.86 & - & 4.37 & - & 3.43 & 45 & 3.34 & 67 & 2.28 \\
\hline $\begin{array}{l}\text { 3.Harbour } \\
\text { infrastructure quality }\end{array}$ & 75 & 3.12 & - & 4.85 & - & 4.09 & 71 & 3.31 & 76 & 3.12 \\
\hline $\begin{array}{l}\text { 4. Air transportation } \\
\text { infrastructure quality }\end{array}$ & 90 & 3.63 & - & 5.40 & - & 4.67 & 92 & 3.48 & 54 & 4.74 \\
\hline $\begin{array}{l}\text { 5. Quality of electric } \\
\text { energy supply }\end{array}$ & 81 & 3.83 & - & 5.97 & - & 5.46 & 75 & 4.02 & 71 & 4.11 \\
\hline 6.Phone lines & 59 & 20.25 & - & 46.76 & - & 35.44 & 35 & 35.31 & 47 & 26.45 \\
\hline
\end{tabular}

Source: Own calculations and data from The Global Competitiveness Report 2006-2007, World Economic Forum, 2007.

The data from Table 2, regarding the competitiveness level of the infrastructure from Romania against other countries reveals the following:

- against the EU-25 and EU-10 Member Countries, Romania records more inferior scores

to all 6 indicators of infrastructure analysed with differences (score lags) as follows: 


\begin{tabular}{|l|c|c|c|c|c|c|c|}
\hline \multirow{2}{*}{$\begin{array}{c}\text { Group of } \\
\begin{array}{c}\text { countries and } \\
\text { countries }\end{array}\end{array}$} & $\begin{array}{c}\text { Total } \\
\text { infrastructure }\end{array}$ & $\mathbf{1}$ & $\mathbf{2}$ & $\mathbf{3}$ & $\mathbf{4}$ & $\mathbf{5}$ & $\mathbf{6}$ \\
\hline EU-25 & -1.98 & -2.75 & -1.51 & -1.73 & -1.77 & -2.14 & -26.51 \\
\hline EU-10 & -1.23 & -1.98 & -0.57 & -0.97 & -1.04 & -1.63 & -15.19 \\
\hline Bulgaria & -0.36 & -0.29 & -0.48 & -0.19 & +0.15 & -0.19 & -14.88 \\
\hline Turkey & -0.41 & -1.15 & +0.58 & 0.0 & -1.11 & -0.28 & -6.2 \\
\hline
\end{tabular}

* See Table 2 for indicators 1-6 of infrastructure; the signs (+) and (-) mean advantage, respectively disadvantage for Romania, against the groups of countries and countries taken as term of comparison.

Source: Own calculations and data from The Global Competitiveness Report 2006-2007, World Economic Forum, 2007.

- Romania recorded superior scores against Bulgaria only for the air transport quality indicator and, against Turkey, only for railroad infrastructure development while for the rest of the infrastructure indicators Romania is in an inferior situation, more or less.

As it can be noticed, the field of infrastructure, for Romania, represents a vulnerability issue of competitive advantages with direct repercussions on the foreign trade of goods and services of the country, inclusively in the field of tourism.

\section{Macroeconomic competitiveness}

At international level, the pillar of the macroeconomic competitiveness indicators refers to the budgetary deficit/surplus, savings rate, inflation and interest rate, internal and external public debt and exchange rate which represent the basic milestones for any international rating agency.

This pillar of macroeconomic competitiveness is strongly influenced by the economic internal and external conjecture and by the business cycle so that the level of the scores might vary to a significant extent from one year to the other and from one country to another.

Table no. 3

Indicators of Romania's macroeconomic competitiveness, against EU-25, EU-10, Bulgaria and Turkey, in the years 2006-2007

\begin{tabular}{|l|c|c|c|c|c|c|c|c|c|c|}
\hline \multicolumn{1}{|c|}{$\begin{array}{l}\text { Macroeconomic } \\
\begin{array}{c}\text { competitiveness } \\
\text { indicators }\end{array}\end{array}$} & \multicolumn{2}{|c|}{ Romania } & \multicolumn{2}{c|}{ EU-25 } & \multicolumn{2}{c|}{ EU-10 } & \multicolumn{2}{c|}{ Bulgaria } & \multicolumn{2}{c|}{ Turkey } \\
\cline { 2 - 11 } & Position & Score & Position & Score & Position & Score & Position & Score & Position & Score \\
\hline $\begin{array}{l}\text { Macroeconomic } \\
\text { competitiveness, total }\end{array}$ & 97 & 3.94 & - & 4.76 & - & 4.62 & 35 & 4.92 & 111 & 3.58 \\
\hline $\begin{array}{l}\text { 1.Governmental } \\
\text { surplus/deficit }\end{array}$ & 50 & -0.78 & - & -2.01 & - & -2.86 & 20 & 2.31 & 115 & -5.91 \\
\hline 2. Savings rate & 97 & 13.96 & - & 20.71 & - & 19.78 & 89 & 15.85 & 74 & 18.00 \\
\hline 3. Inflation rate & 98 & 9.00 & - & 2.53 & - & 3.18 & 69 & 5.00 & 94 & 8.20 \\
\hline 4. Interest rate & 108 & 13.18 & - & 3.32 & - & 3.69 & 52 & 4.83 & 60 & 5.60 \\
\hline 5. Public debt & 15 & 18.92 & - & 52.03 & - & 42.74 & 29 & 31.91 & 86 & 72.81 \\
\hline 6. Exchange rate & 118 & 23.41 & - & 7.14 & - & 11.47 & 110 & 17.30 & 117 & 22.07 \\
\hline
\end{tabular}

Source: Own calculations and data from The Global Competitiveness Report 2006-2007, World Economic Forum, 2007.

Some of the macroeconomic competitiveness characteristics of Romania in the years 20062007 in an international comparative context (Tables 3 and 4) refer to:

- Romania records a negative score lag against the EU-25 and EU-10 countries for: total macroeconomic competitiveness; savings rate, inflation, interest and exchange rate; 
Table no. 4

Score differences regarding macroeconomic competitiveness between Romania and EU-25, EU10, Bulgaria and Turkey in the years 2006-2007

\begin{tabular}{|l|c|c|c|c|c|c|c|}
\hline \multirow{2}{*}{ Countries } & \multicolumn{7}{|c|}{ Macroeconomic competitiveness indicators } \\
\cline { 2 - 8 } & $\begin{array}{c}\text { Total } \\
\text { competitiveness }\end{array}$ & $\mathbf{1}$ & $\mathbf{2}$ & $\mathbf{3}$ & $\mathbf{4}$ & $\mathbf{5}$ & $\mathbf{6}$ \\
\hline EU-25 & -0.82 & +1.23 & -6.75 & -6.47 & -9.86 & +33.11 & -16.27 \\
\hline EU-10 & -0.68 & +2.08 & -5.82 & -5.82 & -9.49 & +23.82 & -11.94 \\
\hline Bulgaria & -0.98 & +1.53 & -1.89 & -4.0 & -8.35 & +12.99 & -3.89 \\
\hline Turkey & -0.36 & +5.13 & -4.08 & -0.8 & -7.58 & +53.89 & -1.34 \\
\hline
\end{tabular}

"for 1-6 indicator's name see Table 3.

Source: Own calculations, based on Table 3.

- levels of the macroeconomic competitiveness scores better than in the EU-25 and EU-10 countries are recorded at the budgetary deficit rate and for the public debt, while for the rest macroeconomic disadvantages are found;

- the weakest positions of economic competitiveness are recorded by Romania within the 131 countries for the exchange rate, inflation and interest rate.

\section{Competitiveness in the field of higher education and vocational training}

Investments in human capital became nowadays one of the most important factors of intensive economic growth based on the foremost contribution of intangible assets and ICT to increasing incomes and profits. The main indicators that are recommended by experts for determining the relative competitiveness (in international context) of a country in the field are indicators of quantitative nature (number of pupils and students) and of qualitative nature consisting in the quality of the educational system, the share of mathematics and exact sciences, quality of education management, local availability for expert training services and scientific research, the teaching staff for skills and on the job training.

The level of labour force training within secondary and tertiary education for the needs of the internal and external market impacts directly on internal output competitiveness and tradable goods as well as on research, development and innovation as factor for generating competitive advantages in economy. 
Table no. 5

Competitiveness indicators in the field of education in Romania, against EU-25, EU-10, Bulgaria and Turkey in the years2006-2007

\begin{tabular}{|c|c|c|c|c|c|c|c|c|c|c|}
\hline \multirow[b]{2}{*}{ Competitiveness indicators } & \multicolumn{2}{|c|}{ Romania } & \multicolumn{2}{|c|}{ EU-25 } & \multicolumn{2}{|c|}{ EU-10 } & \multicolumn{2}{|c|}{ Bulgaria } & \multicolumn{2}{|c|}{ Turkey } \\
\hline & position & score & position & score & position & score & position & score & position & score \\
\hline $\begin{array}{l}\text { - Higher education } \\
\text { and vocational } \\
\text { training }\end{array}$ & 50 & 4.34 & - & 5.15 & - & 4.84 & 62 & 4.05 & 57 & 4.15 \\
\hline - education quantity & 51 & 4.85 & - & 5.91 & - & 5.74 & 37 & 5.37 & 68 & 4.29 \\
\hline $\begin{array}{l}\text { 1. Number of students in upper } \\
\text { secondary education }\end{array}$ & 63 & 85.09 & - & $\begin{array}{c}103.0 \\
5\end{array}$ & - & 97,88 & 18 & $\begin{array}{c}102,1 \\
2\end{array}$ & 75 & $\begin{array}{c}79,2 \\
3\end{array}$ \\
\hline 2.Number of students & 44 & 40,00 & - & 58,80 & - & 54,80 & 40 & 41,00 & 60 & $\begin{array}{c}29,0 \\
0\end{array}$ \\
\hline -education quality & 40 & 4,41 & - & 4,79 & - & 4,60 & 70 & 3,71 & 60 & 3,92 \\
\hline $\begin{array}{l}\text { 3. Quality of educational } \\
\text { system }\end{array}$ & 51 & 3,83 & - & 4,46 & - & 4,26 & 83 & 3,11 & 73 & 3,25 \\
\hline $\begin{array}{l}\text { 4. Quality in the field of } \\
\text { mathematics and other exact } \\
\text { sciences }\end{array}$ & 11 & 5,52 & - & 4,95 & - & 4,98 & 51 & 4,40 & 57 & 4,31 \\
\hline 5.Management quality & 70 & 3,87 & - & 4,95 & - & 4,57 & 52 & 3,62 & 61 & 4,20 \\
\hline - on the job training shaping & 58 & 3,77 & - & 4,76 & - & 4,18 & 94 & 3,06 & 37 & 4,25 \\
\hline $\begin{array}{l}\text { 6. Local availability of expert } \\
\text { services of scientific research } \\
\text { and training }\end{array}$ & 44 & 4,25 & - & 4,83 & - & 4,26 & 80 & 3,48 & 41 & 4,32 \\
\hline 7. Size of vocational training & 81 & 3,29 & - & 4,70 & - & 4,11 & 114 & 2,64 & 39 & 4,19 \\
\hline
\end{tabular}

Source: same as for the previous table.

As results from Table 5, for none of the indicators included in the competitiveness analysis in the field of higher education Romania exceeded the average levels of EU-25 and EU-10 which highlights the necessity of taking measures for diminishing gaps, particularly for those indicators where Romania has inferior positions such as continuing vocational training and educational management.

\section{Efficiency of the goods market}

The market efficiency pillar, in the context of the global competitiveness indicator, takes a particular position, corroborating a number of 23 indicators regarding the markets for goods and services, competition, export, import, labour market, labour productivity, labour force migration, business environment, etc.

The large number of indicators for the international comparative analysis of competitive advantages in the field of market efficiency is explained, firstly, by the necessity of attempting to catch the complexity of the field within which are shaped and interfere a multitude of factors of economic and extra-economic nature, or influences on various time-horizons. 
Table no. 6

Competitiveness indicators of Romania in the field of goods' market efficiency, against EU-25, EU-10, Bulgaria and Turkey in the years 2006-2007

\begin{tabular}{|c|c|c|c|c|c|c|c|c|c|c|}
\hline \multirow{2}{*}{$\begin{array}{l}\text { Competitiveness } \\
\text { indicators }\end{array}$} & \multicolumn{2}{|c|}{ Romania } & \multicolumn{2}{|c|}{ EU-25 } & \multicolumn{2}{|c|}{ EU-10 } & \multicolumn{2}{|c|}{ Bulgaria } & \multicolumn{2}{|c|}{ Turkey } \\
\hline & position & score & position & score & position & score & position & score & position & score \\
\hline $\begin{array}{l}\text { Market } \\
\text { efficiency }\end{array}$ & 76 & 4.03 & - & 4.73 & - & 4.44 & 90 & 3.75 & 47 & 4.35 \\
\hline A. Goods market & 57 & 4.26 & - & 4.78 & - & 4.40 & 88 & 3.78 & 36 & 4.68 \\
\hline DISTORSIONS & 76 & 3.75 & - & 4.36 & - & 4.15 & 113 & 3.12 & 65 & 3.86 \\
\hline $\begin{array}{l}\text { 1. Costs of agricultural } \\
\text { policy }\end{array}$ & 103 & 3.22 & - & 3.75 & - & 3.71 & 123 & 2.57 & 112 & 2.93 \\
\hline $\begin{array}{l}\text { 2.Efficiency of the } \\
\text { legal framework }\end{array}$ & 88 & 3.07 & - & 4.85 & - & 4.11 & 113 & 2.53 & 56 & 3.81 \\
\hline $\begin{array}{l}\text { 3. Size and effect of } \\
\text { taxes }\end{array}$ & 109 & 2.44 & - & 3.44 & - & 3.69 & 98 & 2.57 & 83 & 2.89 \\
\hline $\begin{array}{l}4 . \quad \text { Number of } \\
\text { procedures for starting } \\
\text { up a business }\end{array}$ & 10 & 5.00 & - & 7.471 & - & 7.88 & 70 & 11.00 & 31 & 8.00 \\
\hline $\begin{array}{l}\text { 5. Time required for } \\
\text { starting up a business }\end{array}$ & 10 & 11.00 & - & 27.55 & - & 33.88 & 44 & 32.00 & 8 & 9.00 \\
\hline COMPETITION & 65 & 4.12 & - & 5.04 & - & 4.70 & 91 & 3.69 & 37 & 4.79 \\
\hline $\begin{array}{l}\text { 6. Intensity of local } \\
\text { competition }\end{array}$ & 59 & 4.89 & - & 5.37 & - & 5.16 & 99 & 4.15 & 27 & 5.44 \\
\hline $\begin{array}{l}\text { 7. Efficiency of anti- } \\
\text { trust policy }\end{array}$ & 67 & 3.63 & - & 5.08 & - & 4.47 & 89 & 3.15 & 34 & 4.68 \\
\hline 8.Imports & 56 & 47.03 & - & 56.02 & - & 66.99 & 15 & 77.36 & 76 & 35.30 \\
\hline $\begin{array}{l}\text { 9. Prevalence of trade } \\
\text { barriers }\end{array}$ & 69 & 4.26 & - & 5.39 & - & 5.16 & 89 & 4.01 & 44 & 4.77 \\
\hline $\begin{array}{l}\text { 10. Restrictions for } \\
\text { foreign ownership }\end{array}$ & 81 & 4.79 & - & 5.56 & - & 5.30 & 101 & 4.34 & 82 & 4.77 \\
\hline MARKET SIZE & 44 & 4.89 & - & 4.93 & - & 4.36 & 87 & 4.53 & 19 & 5.41 \\
\hline 11.Exports & 75 & 33.95 & - & 56.24 & - & 62.85 & 29 & 60.80 & 88 & 28.30 \\
\hline
\end{tabular}

Source: same as Table 5.

The most relevant conclusions to be deducted from the analysis of data in Table 6 aiming at the competitiveness advantages/disadvantages of Romania in the field of the market efficiency components are the following:

a) market efficiency

- the global pillar of market efficiency placed Romania on the position 81, against 69 Turkey and 114 Bulgaria;

- the EU-25 and EU-10 countries, with scores of 4.73, respectively 4.44 exceeded by far Romania's 4.03 score and Bulgaria's of 3.75;

b) for the goods' market indicator which corroborates distortions, competition and size of the market Romania was placed before Bulgaria with a score of 3.75 and on position 76 against, respectively, position 113 and the score of 3.12;

c) in the case of the indicator distortions, Romania was exceeded by the average level of the EU-25 and EU-10 scores and by Turkey, leaving behind Bulgaria;

d) Romania was sensibly exceeded by EU-25, EU-10 countries and Turkey for the indicators regarding the costs of agricultural production, efficiency of legal framework, taxation, number of procedures and required time for starting up a business;

e) with respect to the global competitiveness indicator (competition), Romania exceeded only Bulgaria, being surpassed in its turn by EU-25, EU-10 countries and Turkey;

f) the size of the specific indicator Romanian imports' competitiveness, the country surpassed only the one of Turkey;

g) regarding the trading barriers indicators, Romania recorded inferior values to those from EU-25, EU-10 and Turkey; 
i) after the size of the score regarding the restrictions on foreign ownership, Romania was placed before Bulgaria and Turkey, and under the EU-25 and EU-10 level;

j) with respect to exports' competitiveness, the size of Romania's score was superior to the one from Turkey, being of 33.95 against 28.30 respectively.

Table no. 7

Situation of competitive advantages (+)/disadvantages (-) of the market efficiency indicators in Romania, against EU-25, EU-10, Bulgaria and Turkey

\begin{tabular}{|c|c|c|c|c|}
\hline Category of indicators & EU-25 & EU-10 & Bulgaria & Turkey \\
\hline Market efficiency & - & - & + & - \\
\hline A. Goods market & - & - & + & - \\
\hline DISTORSIONS & - & - & + & - \\
\hline 1.Agricultural policy costs & - & - & + & + \\
\hline 2.Efficiency of legal framework & - & - & + & - \\
\hline 3.Size and effect of taxes & - & - & - & - \\
\hline 4. Number of procedures for starting up a business & - & - & - & - \\
\hline 5. Required time for starting up a business & - & - & - & + \\
\hline COMPETITION & - & - & + & - \\
\hline 6.Intensity of local competition & - & - & + & - \\
\hline 7. Antitrust policy efficiency & - & - & + & - \\
\hline 8.Imports & - & - & - & + \\
\hline 9.Prevalence of trade barriers & - & - & + & - \\
\hline 10.Restrictions for foreign ownership & - & - & + & + \\
\hline MARKET SIZE & - & - & + & - \\
\hline 11.Exports & - & - & - & + \\
\hline
\end{tabular}

*the signs (+) and (-) signify competitive advantages and, respectively, disadvantages of Romania against countries used for comparison

Source: Own calculations based on the data in Table 6.

In conclusion, for the indicator market efficiency pillar we find that Romania (Table 7) records competitive advantages for 11 indicators against Bulgaria and 5 indicators against Turkey, and against EU-25 and EU-10 Romania has competitive disadvantages for all of the analysed indicators.

\section{Flexibility and efficiency of labour market}

The component labour of the market plays a particularly important role in determining the general level of competitiveness and also of total efficiency. We shall analyse in the following some of the relevant indicators of the labour market efficiency and flexibility in Romania as compared with other countries, determined based on the international methodologies consecrated by the EU, WTO and other international institutions. 
Table no. 8

Competitiveness indicators of Romania regarding flexibility and efficiency of labour market, compared with EU-25, EU-10, Bulgaria and Turkey in the years 2006-2007

\begin{tabular}{|c|c|c|c|c|c|c|c|c|c|c|}
\hline \multirow{2}{*}{$\begin{array}{l}\text { Category of } \\
\text { indicators }\end{array}$} & \multicolumn{2}{|c|}{ Romania } & \multicolumn{2}{|c|}{ EU-25 } & \multicolumn{2}{|c|}{ EU-10 } & \multicolumn{2}{|c|}{ Bulgaria } & \multicolumn{2}{|c|}{ Turkey } \\
\hline & position & score & position & score & position & score & position & score & position & score \\
\hline $\begin{array}{l}\text { Labour } \\
\text { markets. } \\
\text { Flexibility and } \\
\text { efficiency }\end{array}$ & 87 & 4.04 & - & 4.34 & - & 4.43 & 16 & 3.99 & 81 & 4.14 \\
\hline 1. Flexibility & 88 & 4.26 & - & 4.22 & - & 4.60 & 78 & 4.40 & 92 & 4.18 \\
\hline $\begin{array}{l}- \text { Employment and } \\
\text { layoff practices }\end{array}$ & 86 & 3.49 & - & 3.35 & - & 3.66 & 76 & 3.70 & 89 & 3.41 \\
\hline $\begin{array}{lll} & \text { Flexibility in } \\
\text { determining wages } & \end{array}$ & 26 & 5.72 & - & 4.44 & - & 5.36 & 38 & 5.57 & 81 & 4.83 \\
\hline $\begin{array}{l}\text {-Cooperation in the } \\
\text { relationship } \\
\text { employee/employer }\end{array}$ & 120 & 3.55 & - & 4.55 & - & 4.79 & 105 & 3.93 & 84 & 4.30 \\
\hline 2. Efficiency & 78 & 3.83 & - & 4.47 & - & 4.26 & 104 & 3.59 & 60 & 4.09 \\
\hline $\begin{array}{ll}\text { Contribution } & \text { of } \\
\text { professional } & \\
\text { management } & \end{array}$ & 76 & 4.16 & - & 5.18 & - & 4.60 & 115 & 3.35 & 63 & 4.40 \\
\hline $\begin{array}{lrr} & \text { Wages } & \text { and } \\
\text { productivity } & \\
\end{array}$ & 36 & 4.51 & - & 4.25 & - & 4.54 & 52 & 4.26 & 59 & 4.09 \\
\hline -Brain drain & 114 & 2.16 & - & 4.08 & - & 3.52 & 121 & 2.02 & 58 & 3.26 \\
\hline $\begin{array}{l}\text { - Women employment } \\
\text { in private sector }\end{array}$ & 80 & 4.5 & - & 4.37 & - & 4.39 & 56 & 4.72 & 69 & 4.61 \\
\hline
\end{tabular}

Source: Global competitiveness Index, World Economic Forum, 2007.

Flexibility and efficiency of the labour market in Romania (Table 8) highlights the following:

- for the aggregated indicator of the labour market flexibility and efficiency, Romania had a better score than Bulgaria, being surpassed by EU-25, EU-10 and Turkey;

- a competitive advantage of Romania, superior to all countries in the comparison was recorded to the flexibility in determining wages and for wages and productivity;

- for the other categories of indicators Romania was, as a rule, surpassed by EU-25 and EU10 and for some of the indicators by Turkey and Bulgaria, with the exception of women employment where Romania had a higher score than EU-25 and EU-10.

Table no. 9

Situation of competitive advantages (+)/disadvantages (-) of the flexibility and efficiency indicators of labour market in Romania, as compared with EU-25, EU-10 countries, Bulgaria and Turkey ${ }^{*}$ in the years 2006 and 2007

\begin{tabular}{|l|c|c|c|c|}
\hline Category of indicators & EU-25 & EU-10 & Bulgaria & Turkey \\
\hline Labour markets: flexibility and efficiency & - & - & + & - \\
\hline 1. Flexibility & - & - & - & + \\
\hline - employment and layoff practices & + & - & - & + \\
\hline - flexibility in determining wages in the relationship & - & - & - & - \\
\hline $\begin{array}{l}\text { cooperation } \\
\text { employee/employer }\end{array}$ & - & - & - & - \\
\hline 2. Efficiency & - & - & - & - \\
\hline - contribution of professional management & + & - & + & + \\
\hline - wages and productivity & - & - & - & \\
\hline - brain drain & + & + & - & - \\
\hline - women employment in private sector
\end{tabular}

the signs (+) and (-) signify the competitive advantages, respectively disadvantages of Romania against the countries considered for comparison.

Source: Own calculations based on data in Table 8 
Romania recorded competitive advantages (Table 9) against EU-25 and Turkey for four of the indicators, against Bulgaria for three indicators, and against EU-10 for two indicators.

\section{Complexity and openness of financial markets}

Within the indicator of market efficiency, as factor of the global competitiveness indicator, the particularities of financial markets are counted among the significant comparative milestones, taking into account the fact that the financial market mediates directly and/or indirectly the development of the ware flows between Romania and foreign partners.

Table no. 10

Romania's competitiveness indicators regarding complexity and openness of financial markets, compared with other countries, in the period 2006-2007

\begin{tabular}{|c|c|c|c|c|c|c|c|c|c|c|}
\hline \multirow[t]{2}{*}{ Category of indicators } & \multicolumn{2}{|c|}{ Romania } & \multicolumn{2}{|c|}{ EU-25 } & \multicolumn{2}{|c|}{ EU-10 } & \multicolumn{2}{|c|}{ Bulgaria } & \multicolumn{2}{|c|}{ Turkey } \\
\hline & position & score & position & score & position & score & position & score & position & score \\
\hline $\begin{array}{l}\text { Financial markets: } \\
\text { complexity and } \\
\text { openness }\end{array}$ & 73 & 3.80 & - & 5.06 & - & 4.48 & 88 & 3.48 & 58 & 4.23 \\
\hline $\begin{array}{l}\text { Complexity/sophistication } \\
\text { of financial market }\end{array}$ & 85 & 3.09 & - & 5.20 & - & 4.36 & 107 & 2.44 & 36 & 4.63 \\
\hline - Access easiness to loans & 58 & 3.41 & - & 4.36 & - & 3.95 & 63 & 3.22 & 73 & 2.98 \\
\hline $\begin{array}{l}\text { - Availability of risk } \\
\text { capital }\end{array}$ & 72 & 3.04 & - & 4.16 & - & 3.60 & 54 & 3.32 & 77 & 2.98 \\
\hline - Bank solidity & 8 & 5.22 & - & 6.21 & - & 5.12 & 81 & 5.10 & 99 & 4.77 \\
\hline $\begin{array}{l}\text { - Access to local capital } \\
\text { market }\end{array}$ & 79 & 4.23 & - & 5.40 & - & 4.78 & 106 & 3.35 & 34 & 5.79 \\
\hline
\end{tabular}

Source: same as in the previous table.

Against the countries considered for comparison, Romania recorded competitiveness advantages as follows:

a) against Bulgaria for the indicators: financial markets (complexity and openness) easiness of access to loans; bank solidarity; access to local capital market;

b) against Turkey, for the indicators: easiness of access to loans; availability of risk capital; bank solidity;

c) the member countries of EU-25 and EU-10 recorded for all indicators superior competitive advantages against Romania.

Romania has a weak position with respect to the access to local capital market indicator.

\section{Technological readiness}

It is unanimously acknowledged that the technological level of a country represents the most significant parameter of characterising and heightening the economic-social competitiveness of the country. Therefore, within the analysis of competitive advantages we have given particular consideration to the role of the technological level.

The rules according to which science and technology develop are strongly marked by a random dimension (which still does not deny a certain "cyclic" development with various amplitudes of the period), as well as strong propagation and dissemination effects (spillovers) or the generation of positive and negative externalities.

The differences of competitiveness between countries are, firstly, generated by the differences of technological level which, as a rule, are higher than the economic and social ones, when we consider, for instance, the digital divide between developed countries and developing countries in certain specialised fields of top technology. 
Table no. 11

Romania's competitiveness indicators in the field of technological readiness, compared with EU25, EU-10, Bulgaria and Turkey in the years 2006-2007

\begin{tabular}{|l|c|c|c|c|c|c|c|c|c|c|}
\hline \multicolumn{1}{|c|}{$\begin{array}{c}\text { Category of } \\
\text { indicators }\end{array}$} & \multicolumn{2}{|c|}{ Romania } & \multicolumn{2}{c|}{ EU-25 } & \multicolumn{2}{c|}{ EU-10 } & \multicolumn{2}{c|}{ Bulgaria } & \multicolumn{2}{c|}{ Turkey } \\
\cline { 2 - 11 } & position & score & position & score & position & score & position & score & position & score \\
\hline $\begin{array}{l}\text { Global } \\
\text { indicator of } \\
\text { technological } \\
\text { readiness }\end{array}$ & 49 & 3,59 & - & 4,74 & - & 4,38 & 68 & 3,21 & 62 & 3,56 \\
\hline- - Technological level & 74 & 3,59 & - & 4,85 & - & 4,28 & 90 & 2,83 & 55 & 4,08 \\
\hline $\begin{array}{l}\text { - Technological } \\
\text { absorption at } \\
\text { company level }\end{array}$ & 72 & 4,55 & - & 5,19 & - & 5,02 & 116 & 3,46 & 25 & 5,41 \\
\hline $\begin{array}{l}\text { - Legal framework of } \\
\text { information } \\
\text { technology and } \\
\text { communication }\end{array}$ & 57 & 3,97 & - & 4,75 & - & 4,32 & 36 & 4,29 & 52 & 3,95 \\
\hline $\begin{array}{l}\text { FDI and technology } \\
\text { transfer }\end{array}$ & 13 & 5,69 & - & 5,09 & - & 5,18 & 89 & 4,63 & 60 & 4,96 \\
\hline - Mobile phones & 54 & 47,13 & - & 92,03 & - & 85,03 & 45 & 60,94 & 52 & 47,99 \\
\hline - Internet users & 49 & 2076 & - & 4478 & - & 4172 & 53 & 1590 & 56 & 1413 \\
\hline - Personal computers & 51 & & - & 34,64 & - & 26,75 & 66 & 5,94 & 72 & 5,12 \\
\hline
\end{tabular}

Source: same as in the previous table

Many competitiveness lags (Table 11) are recorded in Romania against EU-25 and EU-10 for all indicators of technological readiness, save for foreign direct investments and technology transfer. Some competitive advantage is found against Turkey for personal computers, internet users, FDI and technology transfer. Romania surpassed Bulgaria for the following indicators: global indicator of technological readiness; technological level; FDI and technological transfer; internet users; personal computers.

In the hierarchy of the 131 countries considered for the comparison, the weakest position (place 74) was of Romania for the indicator technological level, being still ahead of Bulgaria which is on place 90 .

\section{Business complexity}

The pillar indicator complexity or "sophistication" of business reflects the competitiveness of a country from the viewpoint of the business environment and its interface with the internal and external factors of the market. An economy in transition cannot by, as a rule, just as competitive as a mature market economy, with respect to business sophistication. Knowing the competitive advantages/disadvantages between Romania and other countries has a special importance because it offers milestones for measures and improving the functionality degree of the market mechanisms in the future and of increasing the complexity degree of the businesses in accordance with the trends and performances at European and world level. 
Table no. 12

Romania's competitiveness indicators in the field of business complexity, as compared with EU25, EU-10, Bulgaria and Turkey in the years 2006-2007

\begin{tabular}{|c|c|c|c|c|c|c|c|c|c|c|}
\hline \multirow{2}{*}{$\begin{array}{l}\text { Category of } \\
\text { indicators }\end{array}$} & \multicolumn{2}{|c|}{ Romania } & \multicolumn{2}{|c|}{ EU-25 } & \multicolumn{2}{|c|}{ EU-10 } & \multicolumn{2}{|c|}{ Bulgaria } & \multicolumn{2}{|c|}{ Turkey } \\
\hline & position & score & position & score & position & score & position & score & position & score \\
\hline $\begin{array}{l}\text { Pillar } \\
\text { indicator: } \\
\text { business } \\
\text { complexity }\end{array}$ & 73 & 3.89 & - & 5.07 & - & 4.46 & 84 & 3.59 & 39 & 4.58 \\
\hline $\begin{array}{l}\text { 1.Support networks } \\
\text { and industries }\end{array}$ & 68 & 4.36 & - & 5.29 & - & 4.47 & 78 & 4.14 & 33 & 5.10 \\
\hline $\begin{array}{l}\text { - Number of local } \\
\text { suppliers }\end{array}$ & 68 & 4.59 & - & 5.26 & - & 4.79 & 77 & 4.45 & 29 & 5.37 \\
\hline $\begin{array}{l}\text { - Quality of local } \\
\text { suppliers }\end{array}$ & 69 & 4.12 & - & 5.32 & - & 4.74 & 79 & 3.83 & 39 & 4.83 \\
\hline $\begin{array}{l}\text { 2. Complexity of } \\
\text { companies } \\
\text { operations and } \\
\text { strategies }\end{array}$ & 77 & 3.42 & - & 4.86 & - & 4.15 & 98 & 3.05 & 47 & 4.06 \\
\hline $\begin{array}{l}\text { - Complexity of } \\
\text { production processes }\end{array}$ & 71 & 3.31 & - & 4.96 & - & 4.18 & 116 & 2.52 & 43 & 4.06 \\
\hline $\begin{array}{l}\text { - Marketing } \\
\text { extension degree }\end{array}$ & 74 & 3.94 & - & 5.28 & - & 4.69 & 100 & 3.26 & 53 & 4.67 \\
\hline $\begin{array}{l}\text { - International } \\
\text { distribution control }\end{array}$ & 66 & 3.89 & - & 4.52 & - & 4.01 & 72 & 3.84 & 29 & 4.52 \\
\hline $\begin{array}{l}\text { - Availability in } \\
\text { authority delegation }\end{array}$ & 65 & 3.47 & - & 4.51 & - & 3.89 & 116 & 2.66 & 50 & 3.75 \\
\hline $\begin{array}{l}\text { - Nature of } \\
\text { competitive } \\
\text { advantages }\end{array}$ & 109 & 2.64 & - & 4.69 & - & 3.71 & 108 & 2.66 & 73 & 3.21 \\
\hline $\begin{array}{l}\text { - Presence of the } \\
\text { value chain }\end{array}$ & 73 & 3.29 & - & 5.20 & - & 4.44 & 69 & 3.38 & 37 & 4.15 \\
\hline
\end{tabular}

Source: same as in the previous Table.

In order to have a more clear image of the competitiveness differences between Romania and the countries used for comparison we shall present in the following these favourable differences (advantages) and the unfavourable ones (disadvantages) marked with the signs $(+)$ and, respectively (-) for Romania based on deducting from the score of Romania the scores of the respective countries or of the groups of countries. 
Table no. 13

Competitive advantages (+)/disadvantages (-) of Romania, in the field of business complexity as compared with the EU-25, EU-10 countries, Bulgaria and Turkey"

\begin{tabular}{|l|c|c|c|c|}
\hline Category of indicators & EU-25 & EU-10 & Bulgaria & Turkey \\
\hline Pillar indicator: business complexity & $-1,98$ & $-0,57$ & $+0,3$ & $-0,69$ \\
\hline 1.Networks and support industries & $-0,93$ & $-0,11$ & $+0,22$ & $-0,74$ \\
\hline - Number of local suppliers & $-0,67$ & $-0,20$ & $+0,14$ & $-0,78$ \\
\hline - Quality of local suppliers & $-1,20$ & $-0,62$ & $+0,24$ & $-0,71$ \\
\hline $\begin{array}{l}\text { 2. Complexity company operations and } \\
\text { strategies }\end{array}$ & $-1,44$ & $-0,73$ & $+0,37$ & $-0,64$ \\
\hline - Complexity of production processes & $-1,65$ & $-0,87$ & $+0,79$ & $-0,75$ \\
\hline - Marketing expansion degree & $-1,34$ & $-0,75$ & $+0,68$ & $-0,73$ \\
\hline - Control of international distribution & $-0,63$ & $-0,12$ & $+0,05$ & $-0,63$ \\
\hline - Availability to delegate authority & $-1,04$ & $-0,42$ & $+0,81$ & $-0,28$ \\
\hline - Nature of competitive advantages & $-2,05$ & $-1,07$ & $-0,02$ & $-0,57$ \\
\hline - Presence of the value chain & $-1,91$ & $-1,15$ & $-0,09$ & $-0,086$ \\
\hline
\end{tabular}

Source: Own calculations based on data in Table 12.

The highest disadvantages are recorded by Romania against EU-25 for the indicators nature of competitive advantages, business complexity, presence of value chain and complexity of production processes (Table 13). A gradual diminishment can be noticed for the competitiveness lags of Romania, depending on the development level of the EU Member Countries.

\section{Indicators of innovation competitiveness}

The research, development and innovation activity (RDI) represents the strongest contemporary drive of increasing the competitiveness of the countries. The products with the highest RDI degree, science-intensive, benefit of particular competitive advantages with respect to the demand of the internal and external market and of the prices' level as well. Therefore, in the last period, a special attention is paid to the comparative analysis between countries in this field*, in depth studies and comparison being performed. In this context, a series of indicators of quantitative and qualitative characterisation of RDI inputs and outputs are considered when the strategies and policies in the RDI field are set up, and emphasis is laid on performances and providing for the premises of increasing the innovation capacity based on developing "education pro-research" and for increasing the efficiency of the dissemination degree of RDI results and of the number of patents, licenses and of the knowledge and technology transfer.

\footnotetext{
${ }^{*}$ See, for instance: INNO BAROMETER; INNOVATION European Scoreboard etc.
} 
Table no. 14

Romania's competitiveness indicators in the field of innovation, as compared with EU-25, EU-

10, Bulgaria and Turkey in the years 2006-2007

\begin{tabular}{|c|c|c|c|c|c|c|c|c|c|c|}
\hline \multirow{2}{*}{$\begin{array}{l}\text { Category of } \\
\text { indicators }\end{array}$} & \multicolumn{2}{|c|}{ Romania } & \multicolumn{2}{|c|}{ EU-25 } & \multicolumn{2}{|c|}{ EU-10 } & \multicolumn{2}{|c|}{ Bulgaria } & \multicolumn{2}{|c|}{ Turkey } \\
\hline & position & score & position & score & position & score & position & score & position & score \\
\hline $\begin{array}{l}\text { Pillar } \\
\text { indicator: } \\
\text { Innovation }\end{array}$ & 68 & 3,14 & - & 4,17 & - & 3,54 & 87 & 2,93 & 51 & 3,35 \\
\hline $\begin{array}{l}\text { - Quality of } \\
\text { scientific research } \\
\text { institutions }\end{array}$ & 67 & 3,70 & - & 4,58 & - & 4,03 & 68 & 3,67 & 55 & 3,86 \\
\hline $\begin{array}{l}\text { - Companies } \\
\text { spending for RDI }\end{array}$ & 70 & 3,07 & - & 4,11 & - & 3,52 & 97 & 2,73 & 62 & 3,19 \\
\hline $\begin{array}{l}\text { - Cooperation } \\
\text { university-industry }\end{array}$ & 77 & 2,86 & - & 4,01 & - & 3,47 & 96 & 2,50 & 46 & 3,35 \\
\hline $\begin{array}{l}\text { - Governmental } \\
\text { acquisitions of } \\
\text { advanced } \\
\text { technologies } \\
\text { products }\end{array}$ & 74 & 3,64 & - & 4,06 & - & 3,70 & 104 & 3,21 & 62 & 3,77 \\
\hline $\begin{array}{l}\text { - Availability of } \\
\text { researchers and } \\
\text { engineers }\end{array}$ & 41 & 4,85 & - & 5,12 & - & 4,72 & 49 & 4,68 & 44 & 4,76 \\
\hline - Patents & 56 & 0,32 & - & 35,74 & - & 2,96 & 51 & 0,39 & 70 & 0,10 \\
\hline $\begin{array}{l}\text { - Intellectual } \\
\text { property protection }\end{array}$ & 80 & 3,13 & - & 4,99 & - & 4,04 & 98 & 2,71 & 71 & 3,28 \\
\hline $\begin{array}{ll} & \text { Innovation } \\
\text { capacity }\end{array}$ & 85 & 2,87 & - & 4,53 & - & 3,77 & 79 & 2,90 & 47 & 3,54 \\
\hline
\end{tabular}

Source: same as the previous tables.

The weakest positions in the hierarchy of the 131 countries were held by Romania for the indicators: innovation capacity, protection of intellectual property, cooperation universitiesindustries; companies spending on RDI.

Bulgaria recorded the most unfavourable positions for the indicators: governmental acquisitions of advanced technology products, protection of intellectual property; companies spending on RDI; cooperation universities-industry.

The positions held by Bulgaria in the field of RDI competitiveness indicators were weaker than Romania's (see tables no. 14 and 15). Romania surpassed Turkey's position for the following RDI indicators: available of researchers and engineers, intellectual property protection.

With respect to EU-25 and EU-10 countries, the competitiveness lags of Romania were practically recorded for all RDI indicators (see Table 15), save for the indicator available researchers and engineers where Romania recorded a slight advantage against EU-10*.

\footnotetext{
* This indicator is contested by some experts who consider that its relevance, due to its quantitative nature, is very low.
} 
Table no. 15

Competitive advantages (+)/disadvantages (-), of Romania,in the field of innovation indicators, against EU-25, EU-10,Bulgaria and Turkey, in the years 2006 and 2007

\begin{tabular}{|l|c|c|c|c|}
\hline Category of indicators & EU-25 & EU-10 & Bulgaria & Turkey \\
\hline Pillar indicator: innovation & -1.03 & -0.40 & +0.21 & -0.21 \\
\hline - Quality of scientific research institutions & -0.88 & -0.33 & +0.03 & -0.16 \\
\hline - Companies spending for RDI & -1.04 & -0.45 & +0.34 & -0.12 \\
\hline - Cooperation university-industry & -1.15 & -0.61 & +0.36 & -0.49 \\
\hline - Governmental acquisitions of advanced technology products & -0.42 & -0.06 & +0.43 & -0.13 \\
\hline - Availabilities of researchers and engineers & -0.27 & +0.13 & +0.17 & +0.09 \\
\hline - Patents & -35.42 & -2.64 & -0.07 & +0.12 \\
\hline - Intellectual property protection & -1.54 & -0.59 & +0.74 & +0.17 \\
\hline - Innovation capacity & -1.66 & -0.90 & -0.03 & -0.67 \\
\hline
\end{tabular}

Source: Own calculations based on data from Table 14.

The highest competitive disadvantage of Romania against EU-25 countries is recorded for the indicator patents where, also in EU-10 countries, that is New Members of the EU there is a major gap of more than 10 times against EU-25, with the highest share being the one of the Old Member countries of the EU. The reasons for Romania's lag against other countries for the indicator patents are multiple. Among these we mention brain drain; the brain hunter phenomenon; the relative costs of brevets and barriers of procedural nature; the temptation to sell illegally some discoveries and inventions of Romanian researchers; the weak stimulation and financing of research of excellence.

This comparative analysis of competitive advantages/disadvantages needs to be continued for Romania at the regional and local levels in order to identify "strong" and "weak" points of the national economy for a better priorities setting up and strategies implementation.

\section{References:}

1. Aghion, P. and P. Howitt (1992), „A model of growth through creative destruction”, Econometrica, vol. 51, p. 323-351.

2. Averz, G. si Cameron, F. „The enlargement of the European Union” Sheffield, 1998.

3. Balassa, B.; and L. Bauwens, Changing Trade Patterns in Manufactured Goods: an Economic Investigation, North-Holland, 1988.

4. Barro, R.X. and Sala-i-Martin (1992), „Convergence”, Journal of Political Economy, vol. 100 (2), p. 23-51.

5. Bodea P.C., The tariff equivalent of tariff-rate quotas - a case study apply to the import of an agricultural product in Romania". Review of Economic \&Business Studies nr.1, 2008, p.161-171.

6. Feenstra R.C., (1998) „Trade and Desintegration of Production in the Global Economy", in Journal of Economic Perspectives, vol. 12. no.4/1998 p. 31-50.

7. Gogoneață, E., Ivan-Ungureanu C., Stănică, M., „România - țară membră a Uniunii Europene, Provocările comerțului exterior, Editura Economică.

8. Iancu A., „Real convergence and integration”, Review of Economics\&Business Studies", nr.1, 2008, pp.15-28, Iaşi.

9. Iapadre, L. "Structural Factors and Competitiveness in International Trade: A Reformulation of the constant Market shares Analysis method", proceedings from Recent Developments in International Economics, June 1995.

10. Krugman, P. (1979), „Increasing returns, monopolistic competition and international trade 2", Journal of International Economics, vol.9, p.469-479.

11. Krugman, P. and Venables, A (1995), „Globalisation and the inequalityof nations”, 
NBER Working Paper No. 5098.

12. Masters, W.A. (1995). Guidelines on national comparative advantage and agricultural trade. Agricultural Policy Analysis project, Phase III, Methods and Guidelines, No.2001, USAID, Washington, D.C.

13. Stiglitz, J. „Competition and competitiveness in a New Economy”, www2.gsb.columbia.edu/faculty/jstiglitz/; 2002.

14. Voiculescu D. \&Mereuta, C. „Analiza de competitivitate a economiei românesti”, Ed. Academiei Române, Bucuresti, 1998.

15. xxx (2004). Evaluarea costurilor şi beneficiilor aderării României la UE. IER, Studii de impact II. Ciupagea C. (coord).

16. Zaman, Gh., (2005) „Aspecte macroeconomice privind funcționalitatea sectorului privat în România; Experiențe şi repere strategice ale UE pentru sectorul IMM din România" în volumul „Economia românească în contextul integrării europene”, Editura Junimea, Iaşi;

17. Zaman, Gh., Valentina Vasile(coordonatori).s.a. (2003) „Evoluții structurale ale exportului în România", Editura Expert, Bucureşti; Zaman, Gh., Valentina Vasile(coordonatori); (2004) „Evoluții structurale ale exportului în România. Model de prognoză a exportului şi importului pe ramuri CAEN", Academia Română, IEN, Bucureşti. 